\title{
Long-term Effects of Big Sagebrush Control on Vegetation and Soil Water
}

\author{
DAVID L. STURGES
}

\section{Abstract}

Herbaceous productivity of mountain big sagebrush (A rtemisia tridentata spp. vaseywna) areassprayed with 2,4D (2,4-dichlorophenoxyacetic acid) was nearly twice that of untreated areas 10 years after spraying, while the number of sagebrush plants on treated areas was $4 \%$ of that before spraying. Soil at the Wyoming study site was a Youga loam (Argic Cryoboroll). On treated areas, soil water depletion from the surface $0.9 \mathrm{~m}$ of soil slightly exceeded that of untreated areas beginning the third year after spraying when herbaceous vegetation had fully responded to release from sagebrush competition. Water depletion in soil $0.9 \mathrm{~m}$ to $1.8 \mathrm{~m}$ deep was substantially less on sprayed areas compared to unsprayed areas. Seasonal water depletion in the surface $1.8 \mathrm{~m}$ of soil was reduced $31 \%$ the year of treatment, and about $7 \%$ between 5 and 11 years after treatment. Mathematical relationships were developed to predict the effect of sagebrush control on seasonal water depletion in the surface $1.8 \mathrm{~m}$ of soil, the surface $0.9 \mathrm{~m}$ of soil, and soil 0.9-1.8 m deep.

Control of big sagebrush (Artemisia tridentata) with the herbicide, 2,4-D (2,4-dichlorophenoxyacetic acid) beginning in the late 1940 's revolutionized management of sagebrush rangeland. Millions of acres have been sprayed to benefit livestock forage production. The response by vegetation to spraying has been investigated at numerous locations in years immediately after treatment, but information about reestablishment of big sagebrush on treated areas is less common.

Both biotic and abiotic values are affected by spraying. Hydrologic impacts, for example, have received little attention compared to vegetative responses. The soil water regime may be altered when deeply rooting big sagebrush is replaced by shallower rooting herbaceous species and there is speculation that treatment can increase water yields in some locations.

This paper focuses upon the responses by vegetation and soil water to big sagebrush control 6 to 11 years after treatment. Treatment responses in the first 5 years were previously reported (Sturges 1977).

\section{Vegetation Characteristics}

Spraying big sagebrush vegetation with 2,4-D commonly increases grass production 2 to 3 times above pretreatment levels, where adequate populations of herbaceous species are present (Hull et al. 1952, Hyder and Sneva 1956, Tabler 1968, Miller et al. 1980). Forb production is suppressed by spraying, but control of big sagebrush by burning does not greatly alter vegetative composition (Harniss and Murray 1973, Nimir and Payne 1978).

Sagebrush control is not a permanent type conversion, but the time required for big sagebrush to return to pretreatment levels is quite variable. Harniss and Murray (1973) found that grass and forb production remained above preburn levels for 12 years after a mountain big sagebrush ( $A$. tridentata spp. vaseyana) stand was burned, but was below preburn levels 30 years after treatment. The useful life of a spray project in Oregon exceeded 17 years (Sneva 1972). Sagebrush was a minor vegetation component in the first

Author is research forester, Rocky Mountain Forest and Range Experiment Station, Laramie, Wyo. 82070. Station headquarters is in Fort Collins, in cooperation with Colorado State University. Portion's of the research were supported by the Bureau of Land Management, U.S. Department of the Interior.

Manuscript received July $22,1982$. decade after treatment, but sagebrush density was similar to untreated vegetation in the fifteenth year. Big sagebrush reestablishment was investigated by Bartolome and Heady (1978) in another Oregon study. The age of sagebrush plants growing on sprayed areas indicated that treatment seldom killed all plants and that most reestablishment occurred in years immediately following treatment. Thilenius and Brown (1974) and Johnson (1969) investigated the return of big sagebrush to sprayed areas in Wyoming.

\section{Soil Water Withdrawal Characteristics}

Changes in the soil water regime that follow control of big sagebrush depend upon rooting depths of sagebrush and replacement herbaceous species and upon the depth of soil water recharge (Sturges 1977). Several studies indicate that water withdrawal in the surface meter of soil decreases slightly the first 2 years after sagebrush control. (Sonder and Alley 1961, Cook and Lewis 1963, Tabler 1968, Shown et al. 1972, Sturges 1977). Thereafter, water use by treated and untreated vegetation is similar.

A substantial reduction in seasonal water withdrawal was detected at $\mathbf{2}$ Wyoming sites when mountain big sagebrush was sprayed. Tabler (1968) found that seasonal evapotranspiration decreased $14 \%$ the second year after spraying based on measurements to a $1.8 \mathrm{~m}$ soil depth, while Sturges (1977) detected differences of 19,15 , and $8 \%$ in the first, second, and fifth year after treatment, respectively. Treatment differences in seasonal water use were located almost entirely in soil $0.9 \mathrm{~m}$ to $1.8 \mathrm{~m}$ deep and accrued while vegetation was actively growing. No soil water study extended more than 5 years beyond the treatment year.

\section{Experimental Site}

The study was performed $29 \mathrm{~km}$ west of Saratoga, Wyo., at an elevation of 2,225 m on the Stratton Sagebrush Hydrology study area. Annual precipitation from 1969 to 1980 averaged $52.2 \mathrm{~cm}$ while summer precipitation (June-September) averaged $10.4 \mathrm{~cm}$. About two-thirds of total precipitation fell as snow. A mature stand of mountain big sagebrush inhabited the site at study initiation in 1969. At this time about $20 \%$ of the plants were between 21 and 30 years old, $20 \%$ were 31 to 40 years old, and $35 \%$ of the plants were 41 to 50 years old. Understory vegetation was mainly Idaho fescue (Festuca idahoensis) and blue grasses (Poa spp.). The site was grazed by sheep until the study began, but then was fenced to exclude livestock grazing.

The study site was located on a north-facing hillside in a moderate snow catchment, and except for 2 winters, snowmelt in the spring was sufficient to fully recharge soil water levels. Soil developed in place from sandstone of the Brown's Park Formation and is an Argic Cryoboroll. The A horizon of the Youga series is $36 \mathrm{~cm}$ thick and has a loam texture, while the B horizon is $56 \mathrm{~cm}$ thick and has a loam to clay loam texture. The $\mathbf{C}$ horizon is a gravelly loam and contains numerous rock fragments; roots, however, freely penetrate the horizon.

The 14 0.4-ha experimental units were arranged in 7 randomized blocks; thus each block contained 2 of the 0.4-ha experimental units. Herbicide was applied to 1 randomly selected experimental unit within each block in 1970 while the other unit remained untreated. Treated units were sprayed with 2,4-D appli-d from a truck-mounted spray rig at the rate of $3.1 \mathrm{~kg} \mathrm{ai} / \mathrm{ha}$. $\mathrm{Re}$.ining live 
plants were hand-sprayed the following year, so that sagebrush mortality approached $100 \%$.

\section{Vegetation Measurements}

Herbaceous productivity, including the leaves and current year's twig growth of sagebrush, was measured the year before spraying, the year of spraying, and 1, 2, 3,10 and 11 years after spraying. An electronic capacitance meter was utilized for production measurements on undisturbed experimental units using procedures described by Morris et al. (1976). The capacitance meter was also used on spayed experimental units from 1970-1972, and in 1980. In 1969 production plots on both treatments were clipped and were also clipped on sprayed experimental units in 1973 and 1981. The number of plots that were clipped and that were read with the capacitance meter each year is indicated (Table 1). Clipped and metered plots were 30 by $61 \mathrm{~cm}$ in size and were randomly located each year. Measurements were taken in mid-July as grass species matured. Clipped vegetation was separated into sagebrush, grass, and forb components and oven-dried for 24 hours at $105^{\circ} \mathrm{C}$ before weighing.

Canopy cover of big sagebrush was determined by the line intercept method on all 14 experimental units in 1969. That portion of the sagebrush crown containing live stem or leaf tissue was considered crown intercept; measurements were taken along five randomly located transects within each 0.4 ha experimental unit. Transects were $15.2 \mathrm{~m}$ long and two of them were used to determine sagebrush density by counting the number of plants rooted within a belt $1.3 \mathrm{~m}$ wide and $7.6 \mathrm{~m}$ long $(0.001 \mathrm{ha})$. Canopy cover of sagebrush on unsprayed experimental units was remeasured in 1980 using the same sampling procedures as employed in 1969.

The density of big sagebrush growing on sprayed experimental units 10 years after treatment (1980) was determined by counting the number of plants rooted within circular plots $5.0 \mathrm{~m}$ in diameter $(0.002 \mathrm{ha})$. Sagebrush was counted on 5 randomly located plots in each 0.4 ha experimental unit. No attempt was made to distinguish between sagebrush seedlings and older plants. Bartolome and Heady (1978) noted that big sagebrush can persist as a seedlingsized plant for a number of years, so that age determination based on size is not reliable.

\section{Soil Water Measurements}

Soil water content was measured with a neutron moisture meter at 4 aluminum access tubes randomly located within each 0.4 -ha experimental unit. Six depth measurements, beginning $15 \mathrm{~cm}$ below the surface and continuing to a $168 \mathrm{~cm}$ depth by $30.5 \mathrm{-cm}$ increments, were made in each access tube. Average plot moisture content at the 6 measurement depths on each sampling date was calculated from data collected in individual access tubes. An initial measurement was made each spring immediately following snowmelt, usually in May. A final measurement was made about October 1 , when vegetation growth for the year had been terminated by cold weather.

The change in soil water content between the spring and fall measurement was used to evaluate the effect of sagebrush control on summer water depletion. Water use information was not available in the fourth and sixth year following treatment. Soil water measurements were also taken at 2- to 3-week intervals through the growing season $1,2,3,5,10$, and 11 years after treatment to detect changes in the soil water use pattern in years subsequent to spraying.

\section{Data Analysis}

The 14 0.4-ha experimental units (whole units) were arranged in 7 randomized blocks. Soil water data were analyzed statistically utilizing a split-plot design in which the 6 measurement depths served as subunits. This model permitted testing for differences in soil water withdrawal between sprayed and unsprayed experimental units, testing for differences in water use at the 6 measurement depths, and testing for a treatment-depth interaction. A variance analysis was made each year based on the change in soil water content between the first measurement in the spring and the last measurement in the fall. Analyses based on change in soil water content between successive sampling dates were performed in years when data were collected through the growing season. A modified " $t$ " value, calculated for a split-plot experimental design, was used to test treatment differences in water depletion at a given soil depth for significance (Steel and Torrie 1960). Statistical significance in this paper is based on a 0.05 level of probability.

Differences in the composition of vegetation, herbaceous productivity, and canopy cover of sagebrush, between sprayed and unsprayed experimental units were tested for statistical significance within a randomized block design. Analyses were based on the average value of parameters for each 0.4 -ha experimental unit as calculated from replicate measurements on a unit. The yearly variance analyses for sagebrush, grass, and forb yields were based on information collected from clipped plots; the analysis for total herbaceous yield was based on information obtained with the capacitance meter for years this instrument was used. An arcsine transformation was made on herbage composition data before performing the analysis of variance.

\section{Results}

\section{Composition and Yield of Vegetation}

Prior to treatment, experimental units assigned to the spray and nonspray treatments had similar composition (Table 1) and yield characteristics (Fig. 1). Vegetation was dominated by big sagebrush, which contributed about $73 \%$ of total yield while grasses and forbs contributed $23 \%$ and $4 \%$, respectively, of total yield. Environmental factors influencing growth the first 3 years after spraying were comparable to those experienced 10 and 11 years after spraying. Grass and forb production on untreated experimental units averaged $504 \mathrm{~kg} / \mathrm{ha}$ the first 3 years after treatment and $497 \mathrm{~kg} / \mathrm{ha}$ in the tenth and eleventh posttreatment years.

The response of vegetation to treatment was comparable to that reported from other studies following control of big sagebrush with 2,4-D. Grass yields were 2.4 times greater on sprayed experi-

Table 1. The number of herbaceous production plots clipped and read with the capacitance meter in each experimental unit and percentage composition of vezetation for sprayed and untreated experimental units.

\begin{tabular}{|c|c|c|c|c|c|c|c|c|c|c|}
\hline \multirow[b]{3}{*}{ Year } & \multicolumn{4}{|c|}{ No. plots/exp. unit } & \multicolumn{6}{|c|}{ Percent composition } \\
\hline & \multicolumn{2}{|c|}{ Spray } & \multicolumn{2}{|c|}{ Unspray } & \multicolumn{2}{|c|}{ Sagebrush } & \multicolumn{2}{|c|}{ Grass } & \multicolumn{2}{|c|}{ Forb } \\
\hline & Clipped & Meter & Clipped & Meter & Spray & Unspray & Spray & Unspray & Spray & Unspray \\
\hline 1969 & 10 & 0 & 10 & 0 & 74 & 71 & 22 & 25 & 4 & 4 \\
\hline 1970 & 2 & 15 & 2 & 15 & 0 & $63^{*}$ & $\overline{92}$ & $29 *$ & 8 & 8 \\
\hline 1971 & 5 & 10 & 5 & 10 & 0 & $61 *$ & 99 & $35 *$ & 1 & $4^{*}$ \\
\hline 1972 & 5 & 10 & 5 & 10 & 0 & $67 *$ & 98 & $29 *$ & 2 & 4 \\
\hline 1973 & 10 & 0 & 5 & 10 & 0 & $66^{*}$ & 98 & $29 *$ & 2 & $5^{*}$ \\
\hline 1980 & 2 & 10 & 2 & 10 & 0 & $48^{*}$ & 96 & $45^{*}$ & 4 & 7 \\
\hline 1981 & 6 & 0 & 2 & 10 & 3 & $54^{*}$ & 95 & $45^{*}$ & 2 & 1 \\
\hline
\end{tabular}

-Significant difference between treatments at the 0.05 level of probability. 


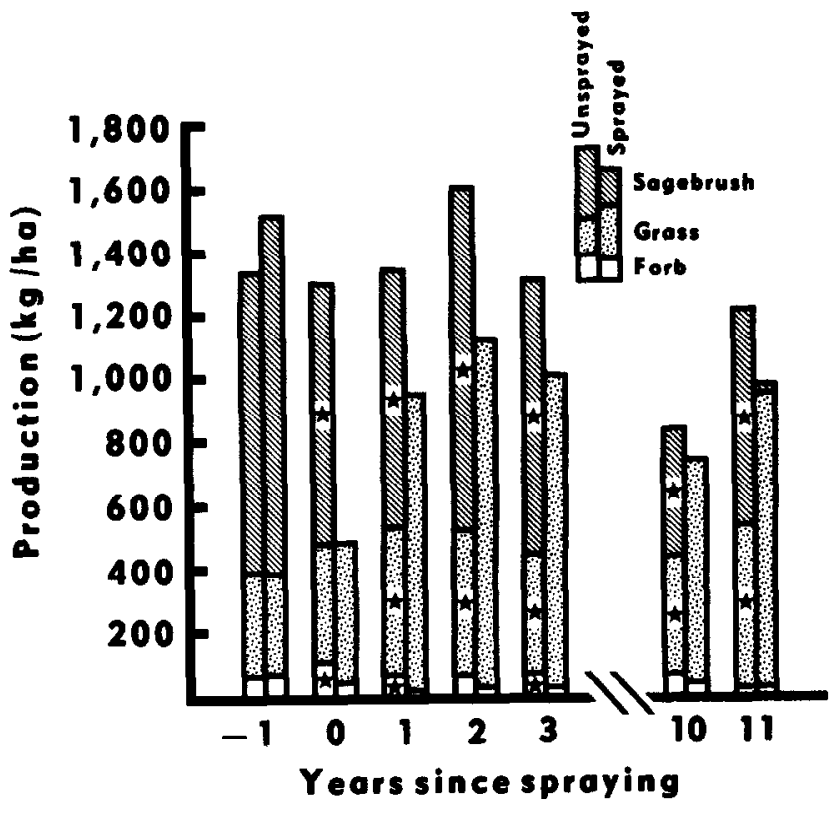

Fig. 1. Herbaceous productivity of vegetation at sprayed and unsprayed experimental untis through 11 years after treatment. A star indicates that treatment differences for that class of vegetation are significant at a 0.05 level of probability. Total herbaceous yields were significantly reduced by spraying $0,1,2$, and 3 years after treatment.

mental units than on unsprayed units in the 3 years after spraying and 1.9 times greater 10 and 11 years after spraying. Thus, there appeared to be some slippage in treatment effect with time. Grass yields of treated experimental units were significantly higher than those of untreated experimental units in all posttreatment years while forb yields were depressed significantly 0 , 1 , and 3 years after spraying.

The total yield of vegetative matter was significantly reduced by spraying in all but the tenth and eleventh posttreatment years because increased grass yields did not completely compensate for the loss of big sagebrush herbage. This aspect of treatment is not considered when effects of sagebrush control are evaluated only in terms of livestock grazing values. However, the decrease in total production has important hydrologic implications because of the use of soil water by vegetation.

\section{Big Sagebrush Characteristics}

Big sagebrush established on sprayed experimental units after treatment despite a high herbaceous productivity level and the absence of livestock grazing. However, it was a minor vegetation component in the first decade following treatment. Sagebrush's density was 50,700 plants/ ha before treatment and 2,100 plants/ ha 10 years after treatment. The distribution of sagebrush plants was spotty in 1980 and about a third of sample locations were still free of sagebrush (Fig. 2). Small areas of bare soil or disturbed sites such as ground squirrel or badger holes provided favorable locations for seedling establishment.

The importance of big sagebrush on unsprayed experimental units decreased sharply between 1973 and 1980. Canopy cover of sagebrush was $27.5 \%$ in 1969 and $18.1 \%$ in 1980 , a significant reduction. Herbage yields of sagebrush were sharply lower in 1980 and 1981 compared to previous years (Fig. 1) and its contribution to total production also decreased (Table 1 ). The advanced age of the stand, rodent depredation, but primarily damage inflicted by an unidentified fungus, contributed to the decline of sagebrush. The snowmold fungus was first noticed in 1973 following snowmelt and damage caused by the fungus was readily apparent in subsequent years. ${ }^{1}$ In a given year, the fungus only attacked individual

\footnotetext{
"“A Snowmold Disease of Mountain Big Sagebrush (Artemisia tridentata vaseyana). D.L. Nelson and D.L. Sturges. Paper presented at the Society for Phytopathology, Salt Lake City, Utah, August, 1982".
}

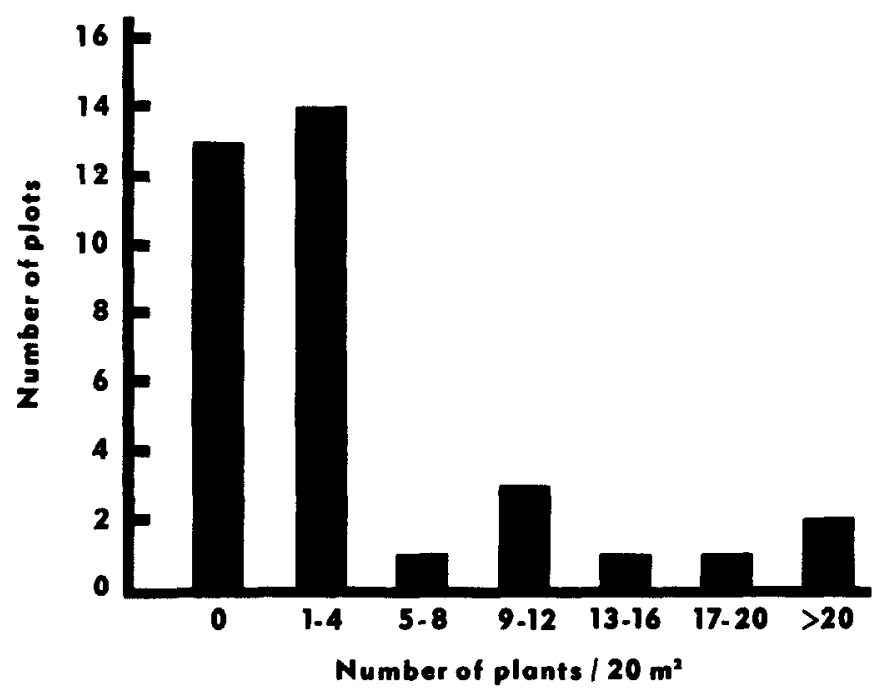

Fig. 2. Density of big sagebrush on treated experimental units 10 years after spraying with 2,4-D. Five plots that were $20 \mathrm{~m}^{2}$ were sampled on each 0.4 ha experimental unit.

branchlets of the sagebrush canopy, but entire plants were sometimes killed after a few years.

Rodents (presumably voles [Microtus spp.]) caused localized mortality of big sagebrush by girdling the trunk of plants growing on untreated experimental units during the 1971-72 and 1979-80 winters. A similar phenomenon attributable to voles was noted by Mueggler (1967) and Tabler (1968). Frischknecht and Baker (1972) believed conditions favoring such depredation occur when vole numbers suddenly increase on sagebrush rangelands that have a dense herbaceous understory and that are snow-covered through the winter. Such conditions occur almost every winter at the study site.

\section{Soil Water Depletion}

Soil water withdrawal characteristics for experimental units assigned to the spray and nonspray treatments were statistically similar the year before treatment (Table 2) and until herbicide application on June 23, 1970 (Sturges 1973). There was an immediate reduction in water use after treatment; by the end of the season, $31 \%$ less water had been withdrawn from the surface $1.8 \mathrm{~m}$ of soil on sprayed experimental units compared to the amount withdrawn from undisturbed units. The reduction in water use was attributable to loss of sagebrush, because the combined yield of grasses and forbs was almost identical for both treatments (Fig. 1). Differences in seasonal water use between treated and untreated vegetation decreased the first 3 years after spraying, but then stablized at about a 7\% difference in later years of study.

The response in the soil water regime was inversely related to the response in herbaceous production. Depletion was reduced $31 \%$ the year of spraying when total herbaceous yields were $37 \%$ as large as those by undisturbed vegetation. Total herbaceous productivity of treated experimental units was $77 \%$ as large as that by undisturbed experimental units 3 years after spraying and $89 \%$ and $80 \%$ as large in the tenth and eleventh year, respectively, when there was about a $7 \%$ difference in seasonal water withdrawal.

Differences in seasonal water withdrawal between treatments did not accrue uniformly through the $1.8-\mathrm{m}$ deep measurement zone (Fig. 3). In the year of spraying, less water was withdrawn on sprayed experimental units than on unsprayed units at all soil depths (Sturges 1973). After this, water use in the surface $0.9 \mathrm{~m}$ of soil was essentially the same for both treatments. Consequently, reductions in soil water depletion after the treatment year were realized almost entirely from soil $0.9 \mathrm{~m}$ to $1.8 \mathrm{~m}$ deep.

Information collected about the timing of soil water use during the growing season also reflected the reduction in treatment effect with time. The reduction in water withdrawal on sprayed experimental units compared to untreated units the year after spraying 
Table 2. Yearly measurement interval, precipitation, and seasonal soil water depletion for experimental units sprayed with 2,4-D in 1970, and experimental units that remained in an undisturbed condition.

\begin{tabular}{|c|c|c|c|c|c|c|}
\hline Year & Treatment & $\begin{array}{l}\text { Years after } \\
\text { treatment }\end{array}$ & $\begin{array}{l}\text { Measurement } \\
\text { interval }\end{array}$ & $\begin{array}{c}\text { Interval } \\
\text { precipitation }\end{array}$ & $\begin{array}{l}\text { Seasonal } \\
\text { depletion }\end{array}$ & $\begin{array}{c}\text { Decrease in } \\
\text { depletion } \\
(\%)\end{array}$ \\
\hline 1969 & $\begin{array}{l}\text { Sprayed } \\
\text { Unsprayed }\end{array}$ & -1 & $05 / 13-09 / 29$ & 11.6 & $\begin{array}{l}25.5 \\
24.6\end{array}$ & +4 \\
\hline 1970 & $\begin{array}{l}\text { Sprayed } \\
\text { Unsprayed }\end{array}$ & 0 & $05 / 27-09 / 30$ & 16.1 & $\begin{array}{l}14.3 \\
20.8\end{array}$ & 31 \\
\hline 1971 & $\begin{array}{l}\text { Sprayed } \\
\text { Unsprayed }\end{array}$ & 1 & $05 / 23-09 / 14$ & 7.7 & $\begin{array}{l}18.3 \\
22.0\end{array}$ & 17 \\
\hline 1972 & $\begin{array}{l}\text { Sprayed } \\
\text { Unsprayed }\end{array}$ & 2 & $05 / 18-10 / 04$ & 12.1 & $\begin{array}{l}17.3 \\
20.4\end{array}$ & ${ }^{c} 15$ \\
\hline 1973 & $\begin{array}{l}\text { Sprayed } \\
\text { Unsprayed }\end{array}$ & 3 & $05 / 31-10 / 04$ & 13.7 & $\begin{array}{l}25.9 \\
29.1\end{array}$ & ${ }^{h} 11$ \\
\hline 1975 & $\begin{array}{l}\text { Sprayed } \\
\text { Unsprayed }\end{array}$ & 5 & $06 / 02-09 / 30$ & 5.8 & $\begin{array}{l}23.9 \\
26.0\end{array}$ & 8 \\
\hline 1977 & $\begin{array}{l}\text { Sprayed } \\
\text { Unsprayed }\end{array}$ & 7 & $04 / 28-10 / 06$ & 18.9 & $\begin{array}{l}23.0 \\
25.3\end{array}$ & 9 \\
\hline 1978 & $\begin{array}{l}\text { Sprayed } \\
\text { Unsprayed }\end{array}$ & 8 & $05 / 15-10 / 02$ & 13.1 & $\begin{array}{l}29.4 \\
30.4\end{array}$ & 3 \\
\hline 1979 & $\begin{array}{l}\text { Sprayed } \\
\text { Unsprayed }\end{array}$ & 9 & $06 / 04-10 / 02$ & 7.1 & $\begin{array}{l}29.9 \\
33.2\end{array}$ & ${ }^{b} 10$ \\
\hline 1980 & $\begin{array}{l}\text { Sprayed } \\
\text { Unsprayed }\end{array}$ & 10 & $05 / 27-10 / 02$ & 9.0 & $\begin{array}{l}27.1 \\
29.2\end{array}$ & 9 \\
\hline 1981 & $\begin{array}{l}\text { Sprayed } \\
\text { Unsprayed }\end{array}$ & 11 & $06 / 01-10 / 01$ & 8.6 & $\begin{array}{l}24.7 \\
26.2\end{array}$ & c6 \\
\hline Avg. & $\begin{array}{l}\text { Sprayed } \\
\text { Unsprayed }\end{array}$ & & & 11.2 & 26.1 & \\
\hline
\end{tabular}

'Significantly different at 0.01 level of probability.

'Significantly different at 0.05 level of probability.

'Significantly different at 0.10 level of probability.

was significant between June 10 , and July 20 . Three years after spraying, water use by treated experimental units was significantly less only in the 15-day interval between June 25 and July 10. Late July was the only time water withdrawal on treated experimental units was significantly less 5 and 10 years after spraying. Sagebrush was still actively withdrawing water from deeper soil at this time, but grass-dominated vegetation had largely completed growth for the year.

Seasonal moisture dynamics are indicated for treated and untreated vegetation 2 and 10 years after treatment in soil 0.3- to $0.6-\mathrm{m}$ and $1.2-$ to $1.5-\mathrm{m}$ deep (Fig. 4). Both treatments utilized water primarily from surface soil early in the growing season and
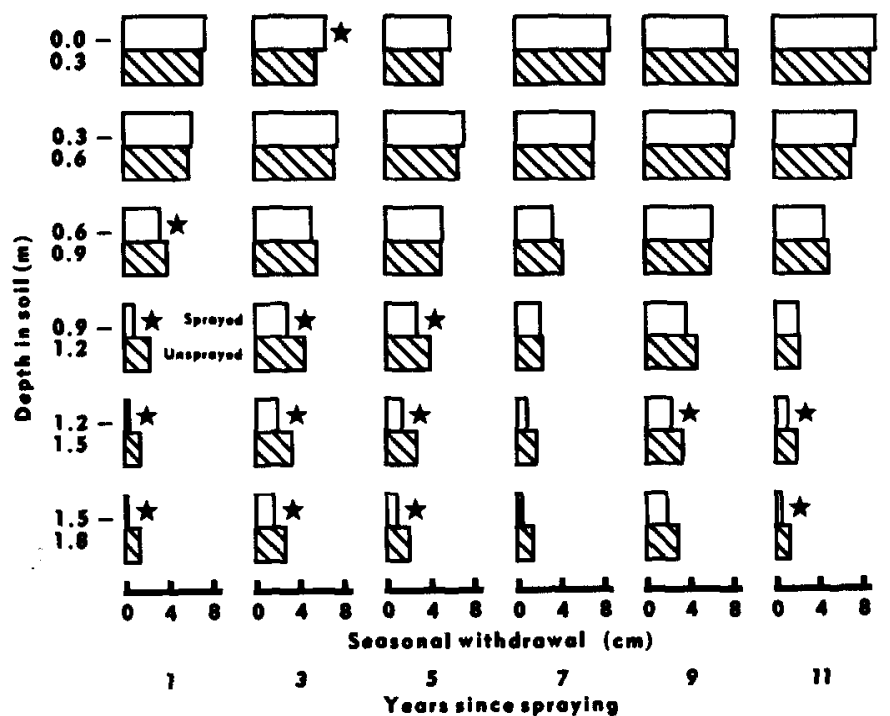

Fig. 3. Seasonal water depletion for sprayed and unsprayed experimental units at six soil depths. A star indicates that seasonal differences between treatments are significant at a 0.05 level of probability. differences in seasonal water use were not significantly different. Water-use shifted to deeper soil in mid-July after surface soil dried. The entire treatment difference at the 1.2- to 1.5-m depth accrued between mid-July and mid-August, when sagebrush roots were actively extracting water. The rate of water use by undisturbed sagebrush vegetation declined sharply after mid-August, which coincided with the time big sagebrush was shedding ephemeral leaves. Seasonal water depletion for sprayed experimental units was significantly less compared to untreated units in soil 1.2- to $1.5-\mathrm{m}$ deep in both the second and tenth year after spraying.

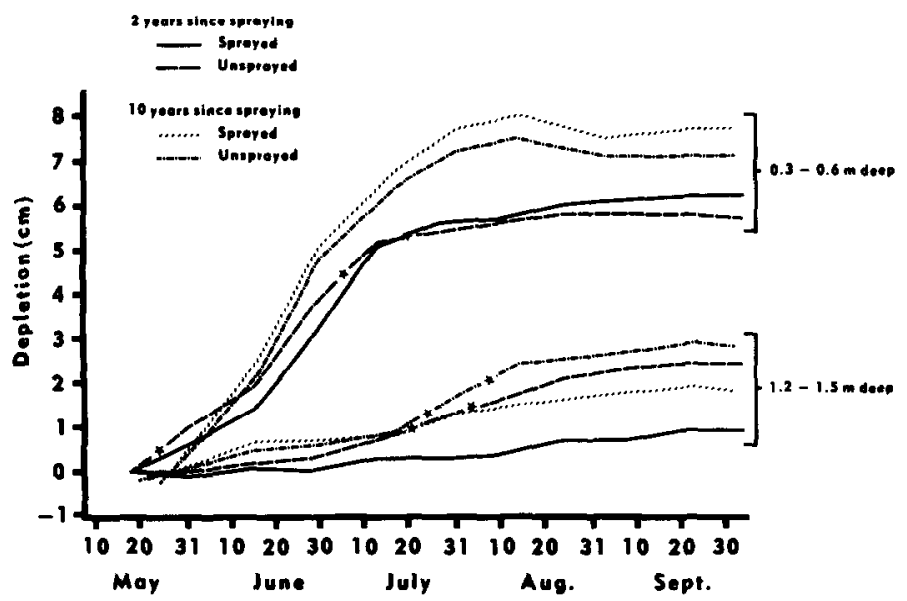

Fis. 4. Soil water depletion at sprayed and unsprayed experimental units in soil $0.3 \mathrm{~m}$ to $0.6 \mathrm{~m}$ deep, and $1.2 \mathrm{~m}$ to $1.5 \mathrm{~m}$ deep, during the second summer and the tenth summer after spraying. A star indicates that the difference in depletion between successive soil water measurement dates attributable to treatment is significant at a 0.05 level of probability. Sagebrush control significantly reduced seasonal water depletion in soil $1.2 \mathrm{~m}$ to $1.5 \mathrm{~m}$ deep both the second and tenth summer after spraying, but seasonal depletion in soil $0.3 \mathrm{~m}$ to $0.6 \mathrm{~m}$ deep was unaffected by treatment. 
Predicting Soil Moisture Response to Big Sagebrush Control

Study data were used to derive empirical relationships relating the reduction in seasonal water withdrawal to time since spraying (Fig. 5). The percent reduction in seasonal depletion between stands of sprayed and unsprayed sagebrush vegetation in the surface $1.8 \mathrm{~m}$ of soil is expressed by:

$$
y=4.38+26.67 /(t)
$$

where $y=$ percentage reduction in fall recharge requirement $t=$ number of years +1 since big sagebrush was controlled

Separate relationships were also derived to express treatment effect in the upper $0.9 \mathrm{~m}$ of soil and in soil $0.9 \mathrm{~m}$ to $1.8 \mathrm{~m}$ deep. The percentage reduction in seasonal depletion between sprayed and unsprayed vegetation in the surface $0.9 \mathrm{~m}$ of soil is expressed by:

$$
y=7.63-5.50 \ln (t)
$$

The percent reduction in seasonal depletion for soil $0.9 \mathrm{~m}$ to $1.8 \mathrm{~m}$ deep is expressed by:

$$
y=66.62-14.85 \ln (t)
$$

Terms in equation (2) and (3) are defined the same as for equation (1). The coefficient of determination $\left(r^{2}\right)$ for equations (1), (2), and (3) was $0.94,0.44$, and 0.81 , respectively.

Prediction equations are based on data collected from a site where soil water is usually recharged completely by snowmelt and where soil was more than $1.8 \mathrm{~m}$ deep. A productive herbaceous understory existed at the site prior to treatment. After spraying, grasses quickly responded to release from sagebrush competition and invasion of sagebrush into treated experimental units was negligible through 11 years. The relationships are applicable only to locations having comparable vegetation, soil, and water recharge characteristics.

\section{Discussion and Management Implications}

The effects of spraying on vegetation productivity and soil water depletion were evaluated on the basis of differences between treated and undisturbed experimental units. However, it is not possible to precisely evaluate how the soil water regime of undisturbed experimental units was affected by snowmold fungus attacking big sagebrush. Water-use efficiency comparisons were made between the 1969-1972 years (before the fungus was active) and the 1973, 1980, and 1981 years (when the fungus was active), based on big sagebrush production and seasonal water change in soil 0.9-1.8 $\mathrm{m}$ deep. Similar calculations based on grass productivity and seasonal depletion in the surface $0.9 \mathrm{~m}$ of soil were also made. These depths were selected because big sagebrush is the primary water user from soil below $1 \mathrm{~m}$, while the principal water reservoir for grasses is located in the upper meter of soil.

Big sagebrush productivity $(\mathrm{kg} / \mathrm{ha})$ per centimeter of water depletion averaged 115 in years before the fungus was active and 72 in years after the fungus was active. The ratio of grass production per centimeter of water depletion was 22 and 17 for the same 2 intervals. The change in the ratio between time periods was considerably larger for sagebrush than for grasses, suggesting that depletion by undisturbed vegetation was affected by the loss of sagebrush. However, if water use on undisturbed experimental units did decrease, the reduction was not as large as the $34 \%$ reduction in sagebrush canopy cover that occurred between 1969 and 1980, because remaining plants used more water to produce a given amount of vegetative matter in later years of the study. Thus, after 1972 , the study probably provides a conservative, but reasonable estimate of changes that occur in the soil water regime following control of big sagebrush.

The study clearly demonstrated that the response in the soil water regime following sagebrush control was different in soil
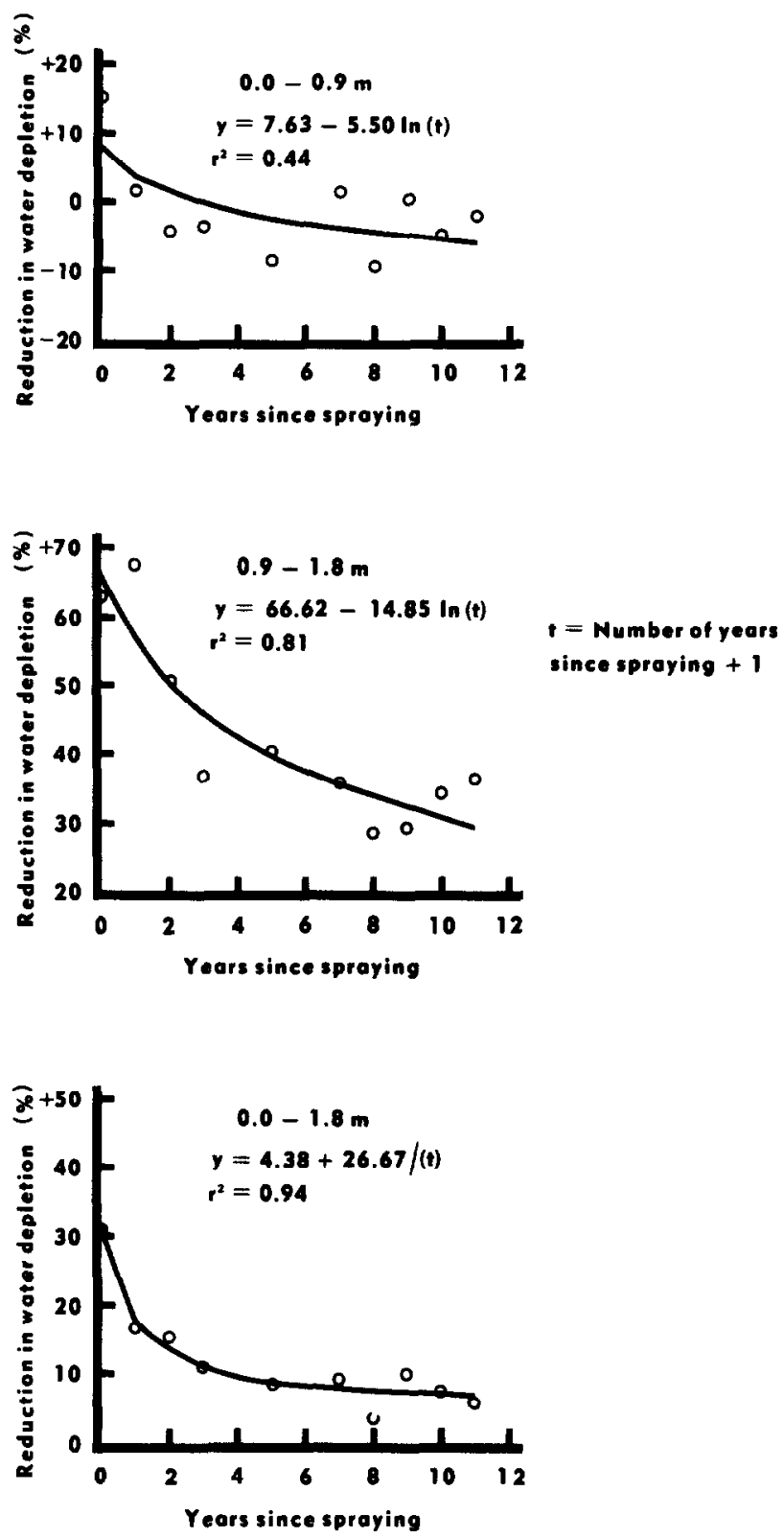

Fig. 5. Field data points through 11 years after spraying and predictive equations showing the percentage reduction in soil water depletion for soil $0.0 \mathrm{~m}$ to $0.9 \mathrm{~m}$ deep, $0.9 \mathrm{~m}$ to 1.8 deep, and $0.0 \mathrm{~m}$ to $1.8 \mathrm{~m}$ deep. The top figure indicates that depletion in the surface $0.9 \mathrm{~m}$ of soil for sprayed areas exceeds depletion for untreated areas beginning the fourth year after spraying.

above and below a depth of $1 \mathrm{~m}$. Except for the year of spraying, water use in the upper $0.9 \mathrm{~m}$ of soil was not materially reduced by spraying. A root-weight study conducted at the same study site supported this conclusion. The weight of roots in the surface $1.2 \mathrm{~m}$ of soil under undisturbed sagebrush vegetation was not significantly different from those of vegetation sprayed 3 years previously (Sturges 1980).

Study findings parallel those of Hyder and Sneva (1956), Cook and Lewis (1963), and Shown et al. (1972), where short-lived reductions in water use were detected in soil up to $0.9 \mathrm{~m}$ deep. Tabler (1968) conducted the only other study in which soil water measurements extended below the surface meter of soil, and found a sizeable reduction in depletion in soil $0.9 \mathrm{~m}$ to $1.8 \mathrm{~m}$ deep. The overall reduction in evapotranspiration for the $1.8-\mathrm{m}$ measurement zone was $14 \%$ the second year after spraying compared to a $15 \%$ difference in soil water depletion detected by this study. 
A relationship based on data collected the first 5 years after spraying was previously developed to relate the reduction in soil water use to time since spraying (Sturges 1977). Field measurements 6 to 11 years after spraying indicate this relationship underestimated the magnitude of treatment effect beyond the fifth year. Equation (1) suggests that there is about a $7 \%$ reduction in soil water withdrawal 10 years after spraying, and a $5 \%$ difference 30 years after spraying. The exact duration of treatment effect at the study site is, or course, unknown. Additional years of information will alter the form of equation (1) to reflect return of big sagebrush to sprayed experimental units. Sagebrush establishment had a negligible effect on the soil water regime in the first 11 years after treatment.

\section{Literature Cited}

Bartolome, James W., and Harold F. Heady. 1978. Ages of big sagebrush following brush control. J. Range Manage. 31:403-406.

Cook, C. Wayne, and Clifford E. Lewis. 1963. Competition between big sagebrush and seeded grasses on foothill ranges in Utah. J. Range Manage. 16:245-250.

Frischknecht, Neil C., and Maurice F. Baker. 1972. Voles can improve sagebrush rangelands. J. Range Manage. 25:466-468.

Hamiss, R.O., and Robert R. Murny. 1973. 30 years of vegetal change following burning of sagebrush-grass range. J. Range Manage. 26:322-325.

Hull, A.C., Jr., N.A. Kissinger, Jr., and W.T. W.T. Vaughn. 1952. Chemical control of big sagebrush in Wyoming. J. Range Manage. 5:398-402.

Hyder, Donald N., and Forreat A. Sneva. 1956. Herbage reponse to sagebrush spraying. J. Range Manage. 9:34-38.

Johnson, W.M. 1969. Life expectancy of a sagebrush control in central Wyoming. J. Range Manage. 22:177-182.
Miller, Richard F., Roger R. Findley, and Jean Alderfer-Findley. 1980. Changes in mountain big sagebrush habitat types following spray release. J. Range Manage. 33:278-281.

Morris, Meridith, J., Kendall L. Johnson, and Donald L. Neal. 1976. Sampling shrub ranges with an electronic capacitance instrument. J. Range Manage. 29:78-81.

Muegfler, W.F. 1967. Voles damage big sagebrush in southwestern Montana. J. Range Manage. 20:88-91.

Nimir, Mutasim Bashir, and Gene F. Payne. 1978. Effects of spring burning on a mountain range. J. Range Manage. 31:259-263.

Shown, L.M., G.C. Lusby, and F.A. Branson. 1972. Soil-moisture effects of conversion of sagebrush cover to bunchgrass cover. Water Resour. Bull. 8:1265-1272.

Sneva, Forrest A. 1972. Grazing return following sagebrush control in eastern Oregon. J. Range Manage. 23:174-178.

Sonder, Leslie W., and Harold P. Alley. 1961. Soil-moisture retention and snow-holding capacity as affected by the chemical control of big sagebrush (Artemisia tridentata Nutt.). Weeds 9:27-35.

Steel, Robert G.D., and James H. Torrte. 1960. Principles and procedures of statistics. McGraw-Hill Book Co., New York.

Sturges, David L. 1973. Soil moisture response to spraying big sagebrush the year of treatment. J. Range Manage. 26:444-447.

Sturges, David L. 1977. Soil moisture response to spraying big sagebrush: A seven-year study and literature interpretation. USDA Forest Serv. Res. Pap. RM-188. Rocky Mtn. Forest and Range Exp. Sta., Fort Collins, Colo.

Sturges, David L. 1980. Soil water withdrawal and root distribution under grubbed, sprayed, and undisturbed big sagebrush vegetation. Great Basin Naturalist 40:157-164.

Tabler, Ronald D. 1968. Soil moisture response to spraying big sagebrush with 2,4-D. J. Range Manage. 21:12-15.

Thilenius, John F. and Gary R. Brown. 1974. Long-term effects of chemical control of big sagebrush. J. Range Manage. 27:223-224.

RESEARCH POSITION IN NATURAL RESOURCE ECONOMICS

Applications are invited for the position of natural resource economist at Winrock International, a nonprofit, publicly supported organization with domestic and international agricultural programs. A Ph.D. is required in the economics of forest, range or natural resource development and management. Strong quantitative skills for systems research also is required; degree in forestry or range science is highly desirable.

Duties include systems research and policy analysis with interdisciplinary teams examining the role of livestock in agroforestry and farming systems in the eastern U.S. The economist will develop and lead new projects as well as work on existing studies. Periodic participation in international projects is also required.

Applicants should submit a letter of application, resume, transcripts, and three references to: Dr. Ned Raun, Vice President for Programs, Winrock International, Route 3, Morrilton, Arkansas 72110. Closing date is March 15, 1984, or when position is filled. 